\title{
Renal dysfunction associated with liver transplantation
}

\author{
Rahul M Jindal, Irinel Popescu
}

\begin{abstract}
Summary
It has been known for some time that a variety of liver diseases affect kidney function, but renal dysfunction associated with orthotopic liver transplantation has received scant attention. Although the mechanisms mediating these abnormalities are incompletely defined, advances in the understanding of renal pathophysiology after liver transplantation have made it possible to develop new treatment strategies. Aggressive and early intervention to diagnose and treat renal complications associated with liver transplantation should be the goal for transplant centres.
\end{abstract}

Keywords: orthotopic liver transplantation, renal dysfunction, cyclosporine, dialysis, FK 506

Department of Surgery, Division of Transplantation, Indiana University School of Medicine, Indianapolis, IN 46202, USA

RM Jindal

Division of Liver Transplantation, Mount Sinai Medical Center, New York, NY, USA

I Popescu
Orthotopic liver transplantation is now the accepted treatment for end-stage liver disease, with graft and patient survival approaching that of kidney transplantation. ${ }^{1}$ As surgical techniques and pharmacological options have improved, transplantation has even become an option for patients at extremes of age and those with congenital and complex diseases. ${ }^{2}$ In patients with renal dysfunction, however, with or without the classical hepatorenal syndrome, morbidity and mortality are higher than in liver transplant recipients with normal renal function. ${ }^{3}$

Kidney and liver failure frequently occur together. ${ }^{4}$ Early in the course of liver disease, there may be no signs or symptoms of renal dysfunction. Careful investigation may, however, detect signs of hypoperfusion of the renal cortex. ${ }^{5}$ Sodium and water retention, which is common in end-stage liver disease, is often associated with renal impairment. Its appearance modifies the course of liver disease and is associated with a worse prognosis. In fact, the renal impairment may be fatal if not recognised and treated promptly. The glomerular filtration rate may be increased in patients with cirrhosis due to abnormal sodium and water retention ${ }^{6}$; in most cases, the degree of renal impairment is proportional to the severity of the liver disease. Occasionally, however, these abnormalities may not be demonstrable even with a reduction of up to $50 \%$ of renal function. ${ }^{7}$

Tubular acidosis, unrelated to sodium and water retention, is occasionally associated with cholestatic liver disease. ${ }^{8}$ This may be a manifestation of multiorgan failure in a seriously ill patient, a consequence of infection, a result of a toxic insult to both organs, or represent hepatorenal syndrome. Many patients with pseudo-hepatorenal syndrome may have acute tubular necrosis, with high urinary sodium input, and impaired tubular function. ${ }^{9}$ Others have true hepatorenal syndrome, with low urinary sodium, and apparent maintenance of tubular function. ${ }^{10}$

IgA nephropathy is peculiar to alcoholic cirrhosis, but may also occasionally occur in other forms of cirrhosis. The presumed mechanisms of IgA nephropathy in this situation are thought to be due to impaired clearance of immune complexes by the diseased liver, increased levels of IgA anti-albumin, reduced intrahepatic circulation of IgA and portosystemic shunting of antigens from the gut to the systemic circulation. ${ }^{11}$

Renal function is commonly affected by immunosuppressive drugs and by diseases that affect the kidney and liver simultaneously. Renal dysfunction may be present before orthotopic liver transplantation in recipients with diabetes, hypertension, tubulo-glomerular diseases, and hepatorenal syndrome. Preoperative renal dysfunction is reported to increase peritransplant morbidity and mortality. ${ }^{3}$ The surgical stress of liver transplantation may affect early graft function which may then be exacerbated by cyclosporine or FK506. More commonly, renal complications occur immediately after surgery, aetiologies include a variety of nephrotoxic drugs, including cyclosporine and FK506. ${ }^{12}$ Another common cause of postoperative renal failure is intra-operative haemodynamic disturbances. A gradual deterioration in renal function over the first few weeks after transplantation may also be caused secondarily by primary non-function or delayed function of the allograft. ${ }^{13}$

There is still a debate on the mechanism of ascites and sodium retention in functional disorders associated with end-stage liver disease. The two commonly proposed hypotheses, the 'underfill'14 and 'overflow'15 theories were unable to explain the entire spectrum of renal dysfunction in cirrhosis. The underfill theory proponents believed that sodium retention was the natural consequence of intravascular insufficiency, while the overflow theory implied that the kidney was retaining sodium inappropriately, leading to overfilling. The hypothesis of Schrier $e t a l^{16}$ has gained wider acceptance as it has presented a unified approach. Their peripheral arterial vasodilatation theory proposes that the integrity of the arterial circulation is more important than the total plasma volume in determining sodium and water retention. The primary site of arterial vasodilatation in 


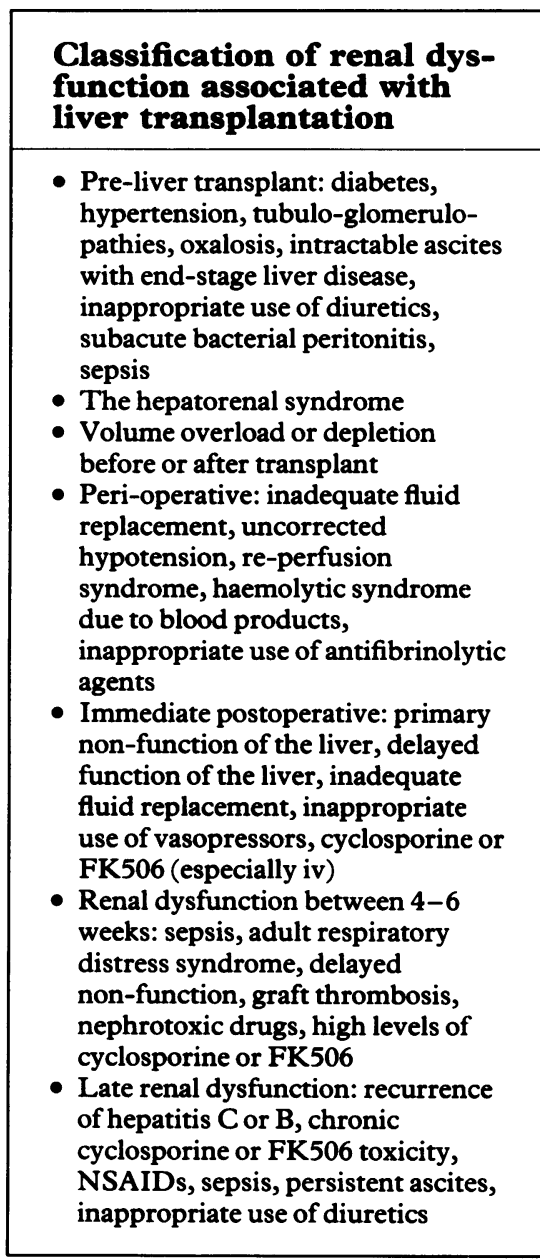

Box 1

\section{Criteria for defining renal failure associated with liver transplant}

Increase in creatinine or blood urea nitrogen, or both, to $132 \mu \mathrm{mol} / \mathrm{l}$ or $50 \mathrm{mg} / \mathrm{dl}$, respectively, in patients with normal pre-operative renal function, or a $50 \%$ increase in either variable in patients with pre-existing renal disease

\section{Classification of degree of renal impairment according to peak creatinine level \\ mild: $<88 \mu \mathrm{mol} / 1$ \\ moderate: $176-265 \mu \mathrm{mol} / \mathrm{l}$ \\ severe: $274-680 \mu \mathrm{mol} / 1$}

cirrhosis was shown in animal experiments to be in the splanchnic circulation, ${ }^{17}$ but evidence for a similar effect in humans is circumstantial ${ }^{18}$ Despite intensive investigations, the precise mediator for vasodilatation is not known. Possible candidates are nitric oxide, prostaglandins, glucagon, vasoactive intestinal polypeptide, calcitonin gene-related peptide, and platelet activating factor. ${ }^{19}$ Recent reports have suggested a role for endothelin. ${ }^{20}$

Several therapeutic options such as diuretics, a low sodium diet, peritoneovenous shunts (LeVeen or Denver shunt), the transjugular intrahepatic portosystemic shunt, and rapid large volume paracentesis, have been proposed to improve renal haemodynamics in patients with cirrhosis. ${ }^{21}$ The therapeutic efficacy of each modality of treatment should be balanced against the frequency of complications. Diuretics must be used judiciously as their use can lead to electrolyte disturbances, prerenal azotemia, and may even precipitate hepatic encephalopathy, ${ }^{22}$ while all shunts are prone to occlusion, infection, and mechanical problems. ${ }^{23}$ However, the transjugular intrahepatic portosystemic shunt, which may be either the Palmaz stent (Johnson \& Johnson, New Brunswick, NJ), or the Wallstent (Schneider, Plymouth, MN) has the advantage of intra-hepatic placement and high patency rates, although it is prone to thrombosis, and may precipitate encephalopathy and heart failure. Repeated large volume paracentesis (4-61/day) with intravenous (iv) albumin replacement has recently gained widespread acceptance. ${ }^{24} \mathrm{~A}$ number of studies have demonstrated the efficacy of this procedure. ${ }^{25}$ Ascites ultrafiltration and reinfusion was not shown to be superior to iv albumin infusion. ${ }^{26}$ Surgical relief of portal hypertension by a variety of portosystemic shunts has been demonstrated to be effective in the treatment of refractory ascites, but carries significant mortality, and has been largely replaced by the radiological placement of transjugular intrahepatic portosystemic shunts. These stents should be placed in specialised centres by skilled interventional radiologists in consultation with a surgical team that has the appropriate skill to manage any possible complications. ${ }^{27,28}$ It may occasionally be necessary to perform surgery on patients with portosystemic shunts, such as those whose shunts have thrombosed. It must, however, be emphasised that these shunts should be considered as a bridge to eventual transplantation. ${ }^{29}$

The widely held belief that chronic renal failure is an absolute contraindication to liver transplantation ${ }^{13}$ has been disproved in recent years. We suggest a scheme for classifying the renal dysfunction associated with liver transplantation that would promote a better understanding of its aetiology and management (box 1). The dictum that a creatinine level greater than $265 \mu \mathrm{mol} / 1^{\star}$ is a contraindication to liver transplantation because of increased morbidity ${ }^{9}$ is no longer true. However, patients with pre-existing renal dysfunction should be considered for a simultaneous liver-kidney transplant. On the other hand, higher creatinine values may be due to hepatorenal syndrome, which may be reversible by transplantation. A renal biopsy is critical in deciding these issues. Percutaneous renal biopsy should be done after correction of coagulopathy, preferably by an interventional radiologist.

\section{Criteria for defining renal failure before and after transplantation}

The absence of a universal definition of posttransplantation renal failure has made inter-centre comparisons difficult. Renal dysfunction has been defined as an increase in creatinine or blood urea nitrogen, or both, to $132 \mu \mathrm{mol} / 1$ or $50 \mathrm{mg} / \mathrm{dl}$, respectively, in patients with normal pre-operative functions, or a $50 \%$ increase in either variable in patients with pre-existing renal disease..$^{30}$ When this definition was applied to 102 consecutive transplant recipients, $26(25.4 \%)$ had pre-operative renal failure, $48 \%$ had renal dysfunction by postoperative day 6 , and $35 \%$ patients had renal failure between postoperative days 7-12. Fifteen $(14.7 \%)$ patients died with renal failure. Seven patients $(6.8 \%)$ required haemodialysis. In a much smaller series in which renal failure was defined as creatinine $>203 \mu \mathrm{mol} / 1,{ }^{31}$ a similar incidence of renal dysfunction (53\%) was found after liver transplant.

Investigators at the University of Pittsburgh found a surprisingly high rate of renal failure $(94.3 \%$ of 105 cases $)$ in the immediate posttransplant period. ${ }^{32}$ They classified the degree of renal impairment as mild, moderate, or severe (see box 2) and found mild renal failure in $36.4 \%$ of patients, moderate failure in $24.2 \%$, and severe impairment in $39.4 \%$. Mortality was $3 \%$ in the mild group, $6.7 \%$ in the moderate group, and $33.3 \%$ in the severe group. Need for peri-operative dialysis was the most important predictor of death in their experience.

\footnotetext{
*The factor used to convert creatinine conventional units to SI units was 88.4.
} 
When the criteria for renal failure were blood urea nitrogen $>50 \mathrm{mg} / \mathrm{dl}$ or creatinine $>176 \mu \mathrm{mol} / 1$, the incidence of renal failure after transplant was $21 \%$ in adults and $22 \%$ in children. ${ }^{33}$ When renal failure was defined as a $100 \%$ rise in creatinine over pretransplant values, the incidence was $66 \%{ }^{34}$ When it was defined as a $50 \%$ increase, $73 \%$ of patients developed either acute or chronic renal failure. ${ }^{35}$ Care should be taken to differentiate renal failure associated with chronic liver disease and hepatorenal syndrome. Table 1 gives the salient points to differentiate between acute renal failure, hepatorenal syndrome and acute necrosis.

\section{The hepatorenal syndrome}

The hepatorenal syndrome is defined as renal failure in patients with liver disease in the absence of clinical, laboratory, or anatomic evidence of known causes of renal failure. It must not be confused with acute renal failure due to acute tubular necrosis, which frequently complicates hepatic and biliary disease, ${ }^{36}$ or with other potentially curable diseases that simultaneously involve the liver and kidney. ${ }^{37}$

The clinical features of hepatorenal syndrome can vary markedly. Renal failure may develop rapidly, even with previously normal renal function. Precipitating factors include rapid paracentesis, inappropriate diuretic therapy, gastrointestinal bleeding, and sepsis. ${ }^{38}$ Classically, hepatorenal syndrome is considered to be functional ${ }^{39}$ because there is full recovery of kidney function after liver transplant. Recovery of kidney function may occasionally be delayed if there is superimposed acute tubular necrosis..$^{40}$ Several studies support the view that hepatorenal syndrome is due to severe arterial vasoconstriction leading to a reduction in renal perfusion. Renal arterial vasoconstriction may be brought about by activation of one or more of the following factors: renin-angiotensinaldosterone system, sympathetic nervous system, atrial natriuretic factors, and antidiuretic hormone. Prostaglandins, ${ }^{41}$ and other potent vasoactive peptides, such as endothelin, ${ }^{20}$ kallikrein, ${ }^{42}$ and endotoxins, ${ }^{43}$ have also been implicated in the pathogenesis of hepatorenal syndrome.

Orthotopic liver transplantation is the only effective treatment for hepatorenal syndrome. ${ }^{44}$ Medical management during the waiting period for transplant includes identification and removal of precipitating factors, correction of volume deficits, prevention of infection, and the use of transjugular intrahepatic portosystemic shunts in selected cases. Renal vasodilators such as prostaglandins have not been shown to be of value in true hepatorenal syndrome. Paracentesis in patients with tense ascites is useful to reduce intraperitoneal pressure, while haemodialysis may be useful to support the patient till a suitable liver allograft becomes available. A variety of hepatic-support devices, currently undergoing trial (discussed later), may eventually provide a bridge to liver transplantation.

Until recently, renal failure was considered a contraindication to liver transplant. Without a transplant, the majority of patients died within a few weeks of the development of renal failure with cirrhosis. ${ }^{45,46}$ Some patients with what appeared to be hepatorenal syndrome, such as two in a series of $200,{ }^{47}$ did recover spontaneously, as did $13 \%$ of 62 in another report, ${ }^{48}$ and $20 \%$ in a third study. ${ }^{49}$

Reversal of hepatorenal syndrome following successful transplant was first described in $1973 .^{50}$ More recently, numerous centres have reported that successful transplant completely reverses hepatorenal syndrome ${ }^{51}$ including a report of long-term survival in four children..$^{52}$ In another series of 102 transplant recipients, 26 had hepatorenal syndrome; of these 11 patients had complete recovery of their renal function after transplantation, although recovery was delayed in the majority..$^{30}$

Stegall et $a l^{33}$ reported experience with hepatorenal syndrome in 23 of 250 patients who underwent liver transplant. Three of the patients died postoperatively, but 20 survived, six of whom required retransplantation. The incidence of primary nonfunction of the allograft was greater in patients with

Table 1 Differential diagnosis of acute renal failure in cirrhosis

\begin{tabular}{|c|c|c|c|}
\hline & $\begin{array}{l}\text { Hepatorenal } \\
\text { syndrome }\end{array}$ & $\begin{array}{l}\text { Prerenal } \\
\text { azotemia }\end{array}$ & $\begin{array}{l}\text { Acute tubular } \\
\text { necrosis }\end{array}$ \\
\hline $\begin{array}{l}\text { Urinary } \mathrm{Na} \\
\text { Flow rate } \\
\text { Urine osmolality } \\
\text { Urine: plasma creatinine ratio } \\
\text { Urine sediment } \\
\text { Response to plasma expansion }\end{array}$ & $\begin{array}{l}<10 \\
\text { oliguria } \\
>\text { serum osmolality } \\
>30: 1 \\
\text { normal } \\
\text { none }\end{array}$ & $\begin{array}{l}<10 \\
\text { oliguria } \\
>\text { serum osmolality } \\
>30: 1 \\
\text { normal } \\
\text { good }\end{array}$ & $\begin{array}{l}>30 \\
\text { oliguria } \\
\text { isotonic } \\
<20: 1 \\
\text { normal } \\
\text { variable }\end{array}$ \\
\hline
\end{tabular}


pre-operative renal insufficiency, but creatinine at discharge was similar between patients with and without hepatorenal syndrome; none required long-term haemodialysis. This report suggested that, although renal failure before surgery is an indicator of higher risk, there was full recovery of renal function after transplant. Gonwa et $a b^{4}$ also compared liver transplant recipients with and without hepatorenal syndrome. Survival at 90 days was comparable between the groups, but survival at one and two years was significantly lower for patients with hepatorenal syndrome. In addition, postoperative complications, including the need for haemodialysis, were more frequent in patients with hepatorenal syndrome.

\section{Combined liver-kidney transplantation}

Several centres have shown that combined liver-kidney transplantation is feasible in patients with end stage disease of both organs. The combined approach has several advantages. When both organs are from the same donor, the transplanted liver protects the renal allograft from antibody-mediated destruction, a phenomenon described as early as 1970.55 Combined liver-kidney transplantation is possible even in patients with preformed lymphocytotoxic antibodies. In a series of 12 patients, there was evidence for a definitive role of the liver in removal of preformed antibodies. ${ }^{56}$

A second advantage is that a well-functioning kidney allows optimal dosing of cyclosporine or FK506. Furthermore, a healthy kidney averts the need for postoperative dialysis and anticoagulation. The longer operative time necessary to perform the combined liver-kidney transplantation did not affect the outcome. ${ }^{57}$

End-stage disease of both organs is the most common indication for combined liver-kidney transplantation..$^{58}$ An accurate diagnosis of renal disease is important, especially in identifying two potentially reversible syndromes: acute renal failure and hepatorenal syndrome. ${ }^{59} \mathrm{Kidney}$ biopsy is crucial in deciding whether a combined procedure is indicated. A decision in favour of combined liver-kidney transplantation is particularly important, because if the kidney transplant is performed later, the immunological advantage of using organs from the same donor is lost.

Primary hyperoxaluria, a rare autosomal recessive disorder, is a particular indication for the combined procedure. The condition is characterised by hyperoxaluria, calcium oxalate urinary lithiasis, and nephrocalcinosis. ${ }^{60}$ Progression to end-stage renal disease is rapid, and therefore, early diagnosis and treatment are imperative. ${ }^{61}$ Unfortunately, however, due to failure of medical treatment or delays in diagnosis, renal failure is still common in patients with primary hyperoxaluria. The diseased kidney can be replaced, but because the metabolic defect persists, the risk of recurrence is high. Liver transplantation for primary hyperoxaluria was first advocated by Watts in 1985.62 By 1991, approximately 30 transplants had been done for primary oxaluria (type 1) worldwide; in the seven surviving recipients, oxalate excretion had been successfully lowered. ${ }^{1}$

Another indication for liver-kidney transplantation is multi-organ cystic disease. Complications of this disorder include cyst-infection, compression, and more rarely, carcinoma arising from the cyst. ${ }^{63}$ Box 3 gives a summary of the features of hyperoxaluria. ${ }^{64}$

\section{Immunosuppression-induced nephrotoxicity}

\section{CYCLOSPORINE}

Nephrotoxicity of cyclosporine has been well documented. These effects may be manifest in the immediate postoperative period, several weeks after transplantation, or after long-term administration of cyclosporine. ${ }^{65,66}$ Intravenous cyclosporine is known to exacerbate the ischaemic injury associated with renal transplantation, this early effect is particularly significant if renal function is compromised before or during surgery. ${ }^{67}$

Cyclosporine nephrotoxicity that becomes evident 2-3 weeks after transplant is associated with deteriorating renal function, usually but not always, with high levels of cyclosporine; renal function usually responds to reduction of cyclosporine. If renal dysfunction persists after a reduction of cyclosporine levels, biopsy of the patient's native kidney may be necessary. Biopsy may reveal pre-existing renal disease, ischaemic damage, or nonspecific changes, and is useful for prognosis of renal failure. ${ }^{68}$

Higher cyclosporine levels after liver transplantation than after renal transplantation have been advocated. ${ }^{69}$ The strategy of maintaining high levels of cyclosporine in liver transplant recipients may result in lowering the dosage of 
steroids. ${ }^{70}$ We have used this strategy at our centres, the rationale being that patient's native kidneys are less susceptible to the nephrotoxicity of cyclosporine, in contrast to patients who receive a kidney transplant. A similar protocol was advocated by researchers at King's College, London, ${ }^{71}$ who identified a small group of liver transplant recipients in whom no clinical factor to account for rejection could be identified. They proposed that rejection may have been precipitated by inadequate immunosuppression. Researchers at the Mayo Clinic $^{72}$ found that low hepatic concentrations of FK506 correlated with early cellular rejection, despite adequate plasma concentrations of FK506. These findings are important as it was shown that patients may suffer from acute rejection despite seemingly adequate levels of cyclosporine or FK506.

There are two approaches to immunosuppression, for recipients of liver transplants. The first is to employ classical immunosuppression (so called triple therapy) with cyclosporine/FK506, azathioprine, and steroids. If renal failure ensues, the patient is dialysed until the failure resolves. The alternative is to induce immunosuppression with OKT3 (Orthoclone OKT3, Ortho Pharmaceutical Corporation), azathioprine and steroids, withholding cyclosporine to promote recovery of renal function. In the presence of mild to moderate rejection, steroids are added (pulse: $1 \mathrm{~g}$ daily for $1-3$ days, followed by taper), cyclosporine is maintained at adequate levels, and compromised renal function is accepted as the price for salvaging the liver. Haemodialysis is initiated during the period of renal failure. Steroid-resistant rejections are treated by the institution of OKT3 for 7-14 days, the duration depending upon the response. An alterative to OKT3 is equine anti-thymocyte globulin (ATGAM, Upjohn Company). This strategy may well change with the introduction of FK506. Centres may now chose to convert their patients with steroid-resistant rejection to FK506 and reserve OKT3 for induction immunosuppression should a retransplant become necessary.

Long-term immunosuppression with cyclosporine has been associated with a slow but steady deterioration in renal function, histology may show severe interstitial fibrosis, ${ }^{73}$ possibly caused by early ischaemic damage. ${ }^{74}$ Late renal failure after liver transplant is treated by haemodialysis or, preferably, by kidney transplantation. If a kidney transplant is indicated in a liver recipient, a case may be made for prioritising the patient because haemodialysis may have a detrimental effect on the liver allograft. Complications associated with dialysis may be obviated by performing a kidney transplant, with substantial improvement in the quality of life.

Although the precise mechanism by which cyclosporine injures the kidney is debated, evidence suggests that it decreases renal blood flow and increases resistance in the afferent arteriole of the glomerulus, leading to a decreased glomerular filtration rate. ${ }^{75}$ There is also evidence that it potentiates vasoconstriction by decreasing renal prostaglandin levels, ${ }^{76}$ and increasing the production of thromboxane, a potent vasoconstrictor. ${ }^{77}$

Recent attempts to wean liver transplant recipients from cyclosporine because of nephrotoxicity have resulted in unacceptable mortality. ${ }^{78}$ Withdrawal of cyclosporine from triple immunosuppression resulted in a high rate of rejection and even death. Of the 12 patients who underwent cyclosporine withdrawal due to nephrotoxicity, two died of rejection, one was placed on FK 506 for rescue, and five had to be restarted on cyclosporine, while the remaining four had stable renal function. Only two patients achieved sustained improvement in renal function.

Steroid-related complications are also a major cause of morbidity and mortality in recipients of liver transplants. Investigators have realised that steroid-withdrawal regimens in recipients of organ transplants would be of considerable long-term advantage. However, in attempting to minimise the side effects of steroids, several centres have reported an increased incidence of acute rejection episodes. A recent meta-analysis of seven randomised, prospective, controlled trials suggested that complete steroid withdrawal resulted in significantly increased incidence of rejections without influencing either patient or graft survival. These trials were conducted in kidney transplant recipients; similar data on liver transplant recipients are awaited. An optimum regimen would obviously be one that would allow the lowest possible use of steroids, but not increase the incidence or severity of rejections and, more importantly, would not result in higher dosing of cyclosporine or FK506. ${ }^{79}$

FK506

FK506 has been approved for use in the US and other countries. Although FK506 is structurally different from cyclosporine, their mechanisms of action on T-cell function are similar. ${ }^{80}$ FK506 is approximately 100 times as potent as cyclosporine. Early reports indicate that FK506 may permit the use of lower doses of steroids, ${ }^{81}$ and it has been shown conclusively to salvage rejecting liver 
allografts. ${ }^{82}$ Initial reports suggested that FK 506 may be less nephrotoxic than cyclosporine, however, it is now clear that of the numerous toxic effects of FK506, renal toxicity is a major cause for concern. ${ }^{83}$

Recently concluded muticentre trials of cyclosporine versus FK506 in liver transplant recipients ${ }^{84,85}$ have shown that FK506 has significant nephrotoxic properties. The European trial ${ }^{84}$ conducted in eight centres included 545 patients in an open, randomised, parallel-group study in which patients were assigned to receive FK506 plus low dose steroids, or to the conventional cyclosporine-based therapy. FK506 therapy was associated with a significant reduction in acute, refractory-acute, amd chronic rejection episodes, despite the lower dosage of steroids. Patient and graft survival rates were not significantly different in the two groups. The most serious complications were renal impairment, diabetogenesis, and neurological toxicity, being more common in the FK506 group. However, there was no significant difference between the median creatinine recorded for the two treatment groups at the end of one year.

The results of the US multicentre trial ${ }^{85}$ involving 478 adults and 51 children at 12 US centres reported similar findings. Although nephrotoxicity was more common with FK506, the mean glomerular filtration rate and creatinine levels were similar in both groups. Specifically, 27 patients in the FK506, and 17 in the cyclosporine group, required haemodialysis or ultrafiltration, a majority in the first 28 days after transplant, and none required long-term dialysis. Comparative complications of FK506 versus cyclosporine in the US trial are given in table 3.

Platz et al $^{86}$ found early renal insufficiency to be about $38 \%$ in cyclosporine and $42 \%$ in FK506 groups, late renal insufficiency was 23\% (cyclosporine) and 29\% (FK506). About $8 \%$ of patients treated with FK506 required haemodialysis, compared to about $11 \%$ in the cyclosporine group. Todo et al from the University of Pittsburgh recently reported their large experience with the use of FK506. They showed that FK506 toxicity on the kidney, pancreas, and nervous

Table 2 Compendium of immunosuppressants (adapted from $\mathrm{H}$ Sollinger, ed. New immunosuppressive drugs. Glenview: Physicians \& Scientists, 1994; pp 1-208)

\begin{tabular}{|c|c|c|c|}
\hline Drug & Proposed mechanism & Major toxicity & Status \\
\hline $\begin{array}{l}T \text {-cell early activa } \\
\text { Cyclosporin A } \\
\text { Cyclosporin G } \\
\text { SDZ IMM } 125 \\
\text { FK506 }\end{array}$ & $\begin{array}{l}\text { tion inhibitor } \\
\text { inhibits SER/THR phosphatase } \\
\text { as above } \\
\text { as above } \\
\text { as above }\end{array}$ & $\begin{array}{l}\text { renal, CNS } \\
\text { renal, CNS } \\
\text { renal, CNS } \\
\text { renal, CNS }\end{array}$ & $\begin{array}{l}\text { FDA-approved } \\
\text { clinical trials } \\
\text { clinical trials } \\
\text { FDA-approved }\end{array}$ \\
\hline $\begin{array}{l}\text { Late activation in } \\
\text { Rapamycin } \\
\text { Leflunomide }\end{array}$ & $\begin{array}{l}\text { hibitors } \\
\text { unclear } \\
\text { inhibits tyrosine kinase }\end{array}$ & $\begin{array}{l}\text { liver, GI } \\
\text { not reported }\end{array}$ & $\begin{array}{l}\text { clinical trials } \\
\text { pre-clinical }\end{array}$ \\
\hline $\begin{array}{l}\text { Antimetabolites } \\
\text { Azathioprine } \\
\text { Methotrexate } \\
\text { Mycophenolate } \\
\quad \text { (RS-61443) }\end{array}$ & $\begin{array}{l}\text { inhibits PRPP amidotransferase } \\
\text { inhibits dihydrofolate reductase } \\
\text { inhibits IMP dehydrogenase }\end{array}$ & $\begin{array}{l}\text { marrow, GI, liver } \\
\text { marrow, mucosa } \\
\text { GI, marrow }\end{array}$ & $\begin{array}{l}\text { FDA-approved } \\
\text { FDA-approved } \\
\text { clinical trials }\end{array}$ \\
\hline $\begin{array}{l}\text { Mizoribine } \\
\text { Brequinar }\end{array}$ & $\begin{array}{l}\text { inhibits IMP dehydrogenase } \\
\text { inhibits DHO dehydrogenase }\end{array}$ & $\begin{array}{l}\text { GI, marrow } \\
\text { marrow, mucosa }\end{array}$ & $\begin{array}{l}\text { pre-clinical } \\
\text { pre-clinical }\end{array}$ \\
\hline $\begin{array}{l}\text { Receptor antagonis } \\
\text { ATG } \\
\text { OKT3 } \\
\text { Anti-Tac } \\
\text { DAB486-IL-2 } \\
\text { Anti-LFA-1 } \\
\text { Anti-ICAM-1 } \\
\text { Soluble HLA } \\
\text { IL-1 antagonist } \\
\text { Deoxyspergualin }\end{array}$ & $\begin{array}{l}\text { ts } \\
\text { kills } \mathrm{T} \text { cells/alters traffic } \\
\text { kills } \mathrm{CD} 3+\text { cells/alters traffic } \\
\text { kills } \mathrm{CD} 25+\text { cells } \\
\text { kills } \mathrm{CD} 25+\text { cells } \\
\text { inhibits intercellular adhesion } \\
\text { inhibits intercellular adhesion } \\
\text { inhibits antigen presentation } \\
\text { inhibits IL-1 receptor } \\
\text { inhibits antigen presentation }\end{array}$ & $\begin{array}{l}\text { serum sickness } \\
\text { cytokine syndrome } \\
\text { none } \\
\text { liver } \\
\text { none } \\
\text { none } \\
\text { not reported } \\
\text { none } \\
\text { marrow, GI }\end{array}$ & $\begin{array}{l}\text { FDA-approved } \\
\text { FDA-approved } \\
\text { clinical trials } \\
\text { clinical trials } \\
\text { clinical trials } \\
\text { clinical trials } \\
\text { pre-clinical } \\
\text { clinical trials } \\
\text { clinical trials }\end{array}$ \\
\hline $\begin{array}{l}\text { Cytokine inhibitors } \\
\text { Anti-IL-6 } \\
\text { Anti-TNF } \\
\text { IL-1 receptor } \\
\text { IL-10 }\end{array}$ & $\begin{array}{l}\text { neutralises IL-6 } \\
\text { neutralises TNF } \\
\text { neutralises IL-1 } \\
\text { inhibits cytokine synthesis }\end{array}$ & $\begin{array}{l}\text { thrombocytopenia } \\
\text { none } \\
\text { none } \\
\text { none }\end{array}$ & $\begin{array}{l}\text { clinical trials } \\
\text { clinical trials } \\
\text { clinical trials } \\
\text { pre-clinical }\end{array}$ \\
\hline $\begin{array}{l}\text { Suppressor induc } \\
\text { SKF105685 } \\
\text { IL-2 }\end{array}$ & $\begin{array}{l}\text { unclear } \\
\text { stimulates via IL-2 }\end{array}$ & $\begin{array}{l}\text { not reported } \\
\text { capillary leak }\end{array}$ & $\begin{array}{l}\text { pre-clinical } \\
\text { clinical }\end{array}$ \\
\hline
\end{tabular}

FDA: Food \& Drug Administration; IL: interleukin; HLA: human eucocyte antigen; CNS: central nervous system; GI: gastrointestinal; SER/THR: serine/threonine; PRPP: 5phosphoribosyl-1-phosphate; IMP: inosine monophosphate; DHO: dihydroorotate dehydrogenase; TNF: tumour necrosis factor 


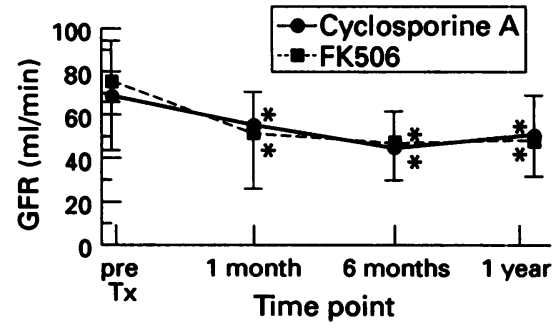

Figure Postoperative glomerular filtration rate (GFR) at the end of one year in recipients of liver transplantation. Cyclosporine- vs FK506-treated patients (adapted from ${ }^{88}$ ). ${ }^{\star} \mathrm{p}<0.05$ compared to pretreatment levels system could be averted by avoiding early postoperative FK506 plasma spike without compromising the liver allograft.

We have analysed the results of a prospective, randomised, trial of cyclosporine $(10 \mathrm{mg} / \mathrm{kg}$ per os (po) before transplant, followed by $1 \mathrm{mg} / \mathrm{kg}$ iv bid in 37 patients) versus FK506 $(0.05 \mathrm{mg} / \mathrm{kg}$ iv, followed by $0.15 \mathrm{mg} / \mathrm{kg}$ po in 30 patients).$^{88}$ Doses were adjusted to plasma drug levels. The steroid protocol in the FK 506 group was $200 \mathrm{mg}$ po prednisone initially, tapered to $20 \mathrm{mg}$ by day 6 ; the cyclosporine group received an initial dose of $1 \mathrm{~g}$, tapered similarly. Creatinine, $24 \mathrm{~h}$ urine output, electrolytes, and need for dialysis were recorded. Glomerular filtration rate was also recorded at one, six and 12 months. Age, sex, primary disease, and severity of liver failure did not differ significantly between groups. Postoperatively, six patients in each group developed renal failure requiring dialysis. FK506 immunosuppression was associated with a higher rate of nephrotoxicity in the immediate postoperative period, but at the end of one year, nephrotoxic effects were similar in both groups of patients (figure).

Some centres have advocated a sequential approach, such as induction with a monoclonal or polyclonal antibody, followed by FK506, to avoid nephrotoxicity. ${ }^{89}$ but this approach may result in the formation of antibodies, and may preclude its use to treat rejection at a later time.

There are conflicting data on the value of switching from cyclosporine to FK506 for renal toxicity. Demetris et $a l^{90}$ reported on 96 liver transplant

Table 3 The incidence of adverse effects ( $\%$ patients) in the US randomised trial $^{85}$

\begin{tabular}{|c|c|c|}
\hline & $F K 506(n=250)$ & Cyclosporine $(n=250)$ \\
\hline $\begin{array}{l}\text { Nervous system } \\
\text { headaches } \\
\text { tremors } \\
\text { insomnia } \\
\text { paresthesia }\end{array}$ & $\begin{array}{l}64 \\
56 \\
64 \\
40\end{array}$ & $\begin{array}{l}60 \\
46 \\
68 \\
30\end{array}$ \\
\hline $\begin{array}{l}\text { Gastrointestinal } \\
\text { diarrhoea } \\
\text { nausea } \\
\text { constipation } \\
\text { abnormal liver function tests } \\
\text { anorexia } \\
\text { vomiting }\end{array}$ & $\begin{array}{l}72 \\
46 \\
24 \\
36 \\
34 \\
27\end{array}$ & $\begin{array}{l}47 \\
37 \\
27 \\
30 \\
24 \\
15\end{array}$ \\
\hline $\begin{array}{l}\text { Cardiovascular system } \\
\text { hypertension }\end{array}$ & 47 & 56 \\
\hline $\begin{array}{l}\text { Renal } \\
\text { increased creatinine } \\
\text { increased blood urea nitrogen } \\
\text { urinary tract infection } \\
\text { oliguria }\end{array}$ & $\begin{array}{l}39 \\
30 \\
16 \\
18\end{array}$ & $\begin{array}{l}25 \\
22 \\
18 \\
15\end{array}$ \\
\hline $\begin{array}{l}\text { Metabolic and nutritional } \\
\text { hyperkalaemia } \\
\text { hypokalaemia } \\
\text { hyperglycaemia } \\
\text { hypomagnesaemia }\end{array}$ & $\begin{array}{l}45 \\
29 \\
47 \\
48\end{array}$ & $\begin{array}{l}26 \\
34 \\
38 \\
45\end{array}$ \\
\hline $\begin{array}{l}\text { Haemic and lymphatic } \\
\text { anaemia } \\
\text { leukocytosis } \\
\text { thrombocytopenia }\end{array}$ & $\begin{array}{l}47 \\
32 \\
24\end{array}$ & $\begin{array}{l}38 \\
26 \\
20\end{array}$ \\
\hline $\begin{array}{l}\text { Miscellaneous } \\
\text { abdominal pain } \\
\text { fever } \\
\text { asthenia } \\
\text { backpain } \\
\text { ascites } \\
\text { peripheral oedema }\end{array}$ & $\begin{array}{l}59 \\
48 \\
52 \\
30 \\
27 \\
26\end{array}$ & $\begin{array}{l}54 \\
56 \\
48 \\
29 \\
22 \\
26\end{array}$ \\
\hline $\begin{array}{l}\text { Respiratory system } \\
\text { pleural effusion } \\
\text { atelectasis } \\
\text { dyspnoea }\end{array}$ & $\begin{array}{l}30 \\
28 \\
29\end{array}$ & $\begin{array}{l}32 \\
30 \\
23\end{array}$ \\
\hline $\begin{array}{l}\text { Skin } \\
\text { pruritus } \\
\text { rash }\end{array}$ & $\begin{array}{l}36 \\
24\end{array}$ & $\begin{array}{l}20 \\
19\end{array}$ \\
\hline
\end{tabular}

The above adverse effects were reported in $>15 \%$ patients. Adapted from package insert (Fugisawa USA, Inc) 
recipients who were converted from cyclosporine to FK506 because of rejection or cyclosporine toxicity. In patients experiencing acute or early chronic rejection, despite optimal cyclosporine-steroid therapy, response to the switch from cyclosporine to FK506 was favourable. Patients with late chronic rejection, however, failed to respond and eventually lost their grafts. At 180 days after conversion from cyclosporine to FK506, there was no change in renal function.

There have been reports on renal allograft pathology in dogs and baboons immunosuppressed with FK506.91,92 The canine kidneys showed acute tubular necrosis, renal artery occlusion, renal vein thrombosis, and atrophy. An oral dose of $1 \mathrm{mg} / \mathrm{kg}$ was immunosuppressive, but animals had acute fibrinoid vasculitis in most organs. A reduced level of $0.5 \mathrm{mg} / \mathrm{kg}$ was not immunosuppressive, but vasculitis was still present. In a study on rodents, ${ }^{93}$ an increase in blood urea nitrogen was observed at day 7 in all three treatment groups (FK506, $1 \mathrm{mg} / \mathrm{kg}$ intramuscularly (im); cyclosporine, $25 \mathrm{mg} / \mathrm{kg}$ po; and FK506 + cyclosporine, while creatinine was raised only in FK506 groups. Moutabarrik et al ${ }^{94}$ showed that exposure of kidney tubular cells to high concentrations of FK506 or cyclosporine induced a time- and dose-dependent cell injury characterised by a direct cytotoxic effect. In a comparison of the effects of FK506 and cyclosporine on endothelial cell function in vitro, and on renal vascular resistance in vivo, FK506 did not induce cell detachment or lysis at any concentration, whereas cyclosporine $(10 \mu \mathrm{M})$ induced a significant reduction in cell count accompanied by cell lysis..$^{95}$ Systemic and renal vascular changes have been studied in the first four weeks after transplantation in patients treated with FK506 or cyclosporine; ${ }^{96}$ FK506 caused less systemic vasoconstriction and hypertension, but the same degree of renal vasoconstriction as cyclosporine.

The multitude of recent data comparing cyclosporine versus FK506 has demonstrated the superiority of FK506-based regimens after liver transplantation without a corresponding increase in renal toxicity. The fact that FK506 can be given orally in the early postoperative period is an important clinical advantage over cyclosporine. There is a need for more studies on the value of switching from cyclosporine to FK506 or vice versa in patients who have severe renal dysfunction after transplant.

OKT3

OKT3 has been used for initial immunoprophylaxis in place of cyclosporine, for preservation of renal function. ${ }^{97-100}$ Millis $e t$ a ${ }^{97}$ reported on 52 patients who were randomised to receive OKT3 (14 days), azathioprine, and steroids vs cyclosporine, azathioprine, and steroids. The groups were matched for age, diagnosis, and Child's classification. Infectious complications were similar in both groups. At 14 days, renal function, as measured by creatinine, was significantly better with OKT 3 than with cyclosporine. Use of OKT3 reduced the incidence of acute early rejection, however, the incidence of rejections after 14 days was similar in both groups. Three patients in each group required dialysis.

The development of anti-OKT3 antibodies can be problematic, but low titres of OKT3 antibody may not be detrimental. ${ }^{101}$ Because low OKT3 levels may result in failure of prophylaxis, ${ }^{102}$ it is necessary to monitor $\mathrm{T}$-cell subsets and serum OKT3 levels. Patients randomised to receive OKT3 or cyclosporine showed that renal function, graft and patient survival, and the incidence of rejection episodes were similar in the two groups at the end of one year. ${ }^{103}$ The OKT3 group, however, had higher levels of anti-OKT3 antibody (39\%). In addition, the incidence of infections was significantly higher in the OKT3 group.

In summary, OKT 3 induction speeds the resolution of renal dysfunction, and limits the need for posttransplant haemodialysis. However, it increases the risk of antibody formation, septic complications, and more importantly, the incidence of lymphoproliferative disease. ${ }^{104}$

Newer immunosuppressants are being evaluated in animal models and in clinical trials. Of these, deoxyspergualin has been shown to have minimal nephrotoxicity. ${ }^{105}$ RS-61443 reportedly does not have any toxic effects on the kidney or liver. ${ }^{106}$ Other immunosuppressive agents, such as brequinar and rapamycin, require further study. The ongoing US multicentre trials of RS-61443 and rapamycin in recipients of kidney transplants are awaited with interest.

\section{Prostaglandins in liver transplantation}

The major prostaglandins in the kidney are $\mathrm{PGE}_{2}, \mathrm{PGF}_{2 \alpha}$, and $\mathrm{PGD}_{2}$. Thromboxane $\mathrm{A}_{2}$ and prostacyclin have also been isolated from the kidney. Renal prostaglandin synthesis occurs in the medulla and cortex. The prostaglandins enter tubular cells by a facilitated transport system, diffuse into the urine, and are partially reabsorbed at the loop of Henle and at the distal tubule. A number of 
physiological functions have been ascribed at least in part to renal prostaglandins, including renin synthesis and release, production and excretion of renal sodium, and modulation of renal vascular resistance and systemic hypertension.

Transport of renal prostaglandins into tubular cells is inhibited by a variety of drugs, including indomethacin, furosemide, and ethacranic acid. This has serious implications after organ transplantation in general. ${ }^{107}$ Non-steroidal anti-inflammatory drugs (NSAIDs) taken inadvertently after liver transplantation have resulted in renal failure requiring haemodialysis; full renal function was eventually recovered (personal observations).

Prostaglandins have been administered to liver transplant recipients for a variety of reasons: to protect the kidney from the effects of iv cyclosporine or FK506, ${ }^{108}$ to treat primary liver nonfunction, ${ }^{109}$ to ameliorate damage due to extended cold preservation of livers, and to treat fulminant liver failure. ${ }^{110}$ Sinclair et $a l^{111}$ from Toronto, Canada, evaluated $\mathrm{PGE}_{1}$ in 17 patients with fulminant liver failure. $P E_{1}$ was well tolerated at a dose of $0.6 \mu \mathrm{g} / \mathrm{kg} / \mathrm{h}$ administered by continuous infusion for up to 28 days. They claimed that $70 \%$ of the patients survived, thereby avoiding transplantation. Subsequently, Sheiner et $a l^{112}$ in a prospective, randomised, double-blind trial of $P G_{1}$ in cases of viral and drug-induced fulminant hepatic failure, failed to show the benefit of prostaglandin therapy. Further large trials will be necessary before a definitive conclusion can be made on the beneficial effects of prostaglandins in liver disorders.

In animal models, and in human recipients of transplanted organs, prostaglandins of the $E$ and I series have exhibited significant immunosuppressive effects. Prostaglandins of the E series have also been shown to provide cytoprotection to the intestinal and gastric mucosa, and prevent post-ischaemic renal injury. ${ }^{113}$ $\mathrm{PGE}_{1}$ has been effective in reversing primary non-function of the transplanted liver and hepatorenal syndrome. ${ }^{114}$ These reports were, however, in small numbers of patients.

In a major randomised, double-blind, placebo-controlled clinical trial of renal transplant recipients, Moran et $a^{115}$ showed that misoprostol improved renal function and reduced the incidence of acute rejection in recipients treated with cyclosporine and prednisone. However, in another large, multicentre trial of renal transplant recipients, Adams et al ${ }^{116}$ reported that enisoprost (PGE) did not have a beneficial effect on the incidence of acute rejections or on the development of renal failure.

In our opinion, routine use of prostaglandins in transplantation outside of controlled trials should be discouraged.

\section{Dialysis in liver transplantation}

Some of the morbidity and mortality that accompanies liver transplantation in patients with renal failure is attributable to side effects of haemodialysis, such as hypotension, cardiovascular instability, coagulopathy, and sepsis. In the presence of primary nonfunction, delayed graft function, or preservation injury, anticoagulation with systemic heparin may compound existing coagulation problems. Hypotension associated with haemodialysis can confuse the postoperative picture, and may lead to the inappropriate use of vasopressors. The use of large amounts of vasopressors may in turn aggravate renal ischaemia.

In a retrospective review, the incidence of acute renal failure in 105 adult liver transplant recipients was $94.2 \%{ }^{9}$ (this figure included mild degrees of renal dysfunction, box 2). Other findings associated with increased mortality included peak serum creatinine $>265 \mu \mathrm{mol} / 1$, multiple transplants, and the requirement for haemodialysis. Pretransplant renal failure did not increase mortality. The most significant predictor of peri-operative death was the need for dialysis.

In unstable patients with end-stage liver disease and renal failure, continuous arteriovenous/venous haemofiltration (CAVH) permits removal of excess fluid and correction of electrolyte abnormalities. CAVH employs a small filter with a membrane highly permeable to water and low molecular weight solutes; the patient's blood pressure is sufficient to maintain filtration and remove excess fluid. CAVH is now an effective alternative in patients who cannot tolerate haemodialysis, despite adequate vasopressors and fluid management.

Haemodialysis has been ineffective in avoiding the need for liver transplantation in hepatorenal syndrome, although it may be useful in carefully selected patients with end-stage liver disease and renal failure. ${ }^{117}$ Haemodialysis with large pore-size polyacrylonitrile membranes may occasionally be useful in hepatic coma, because it permits removal of toxic molecules. ${ }^{118}$ Hakim et al ${ }^{119}$ recently showed that, in patients with acute renal failure, the use of polymethyl methacrylate membrane as compared with the cuprophane (cellulose membrane made from cotton fibres) membrane resulted in improved recovery of renal function, while another report ${ }^{120}$ showed that polyacrylonitrile membranes were 


\section{Learning points}

- liver and kidney failure frequently occur together

- the differential diagnosis of acute renal failure in patients with cirrhosis is between hepatorenal failure, pre-renal azotemia, and acute tubular necrosis

- modalities to improve renal haemodynamics in cirrhotics before liver transplantation include the judicious use of diuretics, low sodium diet, paracentesis, and a variety of shunt procedures

- liver transplantation is the only effective treatment for hepatorenal syndrome

- combined liver-kidney transplantation should be considered for patients with end stage failure of both organs

- renal function is commonly affected by immunosuppressants used to prevent rejection after liver transplantation

- cyclosporine and FK506 (Prograf, Tacrolimus) have significant nephrotoxicity, and should be used carefully with frequent monitoring of drug levels

- haemodialysis and haemofilteration are useful modalities to treat renal failure in liver transplant recipients. The role of prostaglandins is under investigation

- hepatic-assist devices as a bridge to definitive liver transplantation are under intensive investigation

- newer immunosuppressants such as rapamycin, deoxyspergualin, RS-61443, leflunomide, mizoribine, and brequinar sodium are under investigation. Some of these drugs may have reduced nephrotoxicity

- early investigations to diagnose and treat renal dysfunction associated with cirrhosis will reduce mortality and morbidity in recipients of liver transplantation

\section{Box 4}

superior to cuprophane membranes. These reports have suggested that biocompatible membranes are associated with reduction in complement and neutrophil activation, as compared to cellulose membranes.

Other treatment modalities based on the principle of dialysis, such as charcoal-haemoperfusion, cross-haemodialysis in pigs, cuprophane-haemodialysis, and haemoperfusion via extracorporeal devices filled with activated charcoal or ion-exchange resin, have been of minimal or no benefit.

It would be pertinent to discuss briefly some exciting developments in the field of hepatic-assist devices as a bridge to transplantation. Researchers have used artificial devices containing either human liver cells originally derived from either a hepatoblastoma or a pig liver. ${ }^{121}$ Even more exciting was the report by Chari et al $^{122}$ from Duke University, who designed a veno-veno circuit for $e x$-vivo pig-liver perfusion. They treated four patients in liver failure who were critically ill; three had temporary neurological and biochemical improvement, but subsequently died. One patient was stabilised for 10 days, and later received a liver transplant with full recovery. A prospective, controlled trial, in which patients with equal degrees of liver failure are randomly assigned to conventional medical support, artificial liver-assist devices, or $e x$-vivo pig-liver perfusion, will be needed to evaluate the safety and efficacy of these procedures.

Considerable interest has been raised by recent reports of xenotransplantation of livers as an alternative or a bridge to orthotopic liver transplantation. Porcine xenotransplantation was used by investigators at Cedars Sinai Hospital, Los Angeles, to support a critically ill patient until a suitable liver was available, but the attempt was unsuccessful as the patient died within a few hours. ${ }^{123}$ In 1992, two patients with end-stage liver disease received baboon livers at the University of Pittsburgh, unfortunately both patients died, after 26 and 74 days, respectively. ${ }^{124}$ Nevertheless, these attempts have stimulated further research in extracorporeal liver support systems.

\section{Late renal dysfunction due to recurrent hepatitis $C$}

Causes of late renal dysfunction after orthotopic liver transplantation are well documented; these include chronic cyclosporine or FK506 toxicity, use of NSAIDs, sepsis, inappropriate diuretic therapy, and persistent ascites. In addition, recurrence of hepatitis $C$ or $B$ in the transplanted liver may be associated with renal dysfunction. Hepatitis $C$ is a major cause of end-stage liver disease requiring liver transplantation; recurrence of hepatitis is becoming a major problem in this group of patients. At the Mount Sinai Medical Center, New York, ${ }^{125}$ of the 96 patients with hepatitis $C$ transplanted between September 1988 and December 1992, clinical recurrence of hepatitis $C$ was diagnosed in 43 $(44.8 \%)$; mean time from transplantation to recurrence was 206 days. Seven of these patients $(15.9 \%)$ underwent re-transplantation, there were a total of 10 deaths (four in patients without recurrence and six in those whose disease recurred).

The association of renal dysfunction with primary or recurrent hepatitis $C$ raises the possibility of a role for hepatitis $C$ virus in the pathogenesis of mixed cryoglobulinemia. The incidence of anti-hepatitis $\mathrm{C}$ virus antibody was found to be $98 \%$ in patients with essential mixed cryoglobulinemia, but only $2 \%$ in controls (patients with non-cryoglobulinemic glomerulopathies). ${ }^{126}$ In patients with type II cryoglobulinemia, ${ }^{127}$ a $96 \%$ incidence of hepatitis $\mathrm{C}$ virus was documented with a second generation ELISA. In another prospective study of 127 patients with hepatitis $C$, mixed cryoglobulinemia was found in $54 \% .{ }^{128}$ In a series of 19 patients with type II cryoglobulinemia; $42 \%$ had hepatitis $C$ virus antibodies, $84 \%$ had hepatitis $\mathrm{C}$ virus RNA, $26 \%$ had hepatitis $\mathrm{B}$ markers, but only $5.2 \%$ had evidence of active hepatitis B infection, suggesting that type II cryoglobulinemia is strongly associated with concomitant hepatitis $C$ virus infection and occasionally with hepatitis B infection. ${ }^{129}$ In contrast, only two of 13 patients with biopsy-proved chronic hepatitis $\mathrm{C}$ infection were positive for type III cryoglobulinemia, negative samples had low amounts of rheumatoid factor. ${ }^{130}$

We acknowledge the contribution of Martin Milgrom, MD, in reviewing the manuscript.

4 Epstein M. Hepatorenal syndrome. In: Epstein $\mathrm{M}$, ed. The kidney in liver disease. Baltimore: Williams and Wilkins, 1988; pp 89-113.

5 Gentilini P, Lafi G, Buzzelli G, Stefani P, Gentilini P, Lafi G, Buzzelli G, Stefani P,
Masi R. Early renal impairment in chronic Masi $R$. Early renal impairment in chron
liver diseases. Digestion 1980; 20: 73-8.

6 Papper S, Rosenbaum JD. Abnormalities in excretion of water and sodium in compensated cirrhosis of the liver. $f$ Lab Clin Med 1952; 40: 523-30.
7 Gentilini P, Laffi G, Buzzelli G, et al. Functional renal alterations in intrahepatic cholestasis. In: Gentilini P, Popper H, Sherlock S, tasis. In: Gentilini P, Popper H, Sherlock S,
Teodori U, eds. Problems in intrahepatic cholesTeodori U, eds. Problems in intrahepatic
tasis. Basel: Kager, 1979; pp 125-31.

8 Gentilini P. Renal functional impairment in Gentilini $P$. Renal functional impairment in
liver cirrhosis. In: Gentilini P, Arias IM, Arroyo V, Schrier RW, eds. Liver diseases and renal complications. New York: Raven Press,
1990; pp 311-31. 
9 McCauley J, Van Theil DH, Starzl TE, Puschett JB. Acute and chronic renal failure in liver transplantation. Nephron 1990; 55: $121-8$

10 Tygstrup N, Ranek L. Assessment of prognosis in fulminant hepatic failure. Semin Liver Dis 1986; 6: 129-37.

11 Newell GE. Cirrhotic glomerulonephritis: incidence, morphology, clinical features and pathogenesis. Am 7 Kidney Dis 1987; 9: $183-90$

12 Morris PJ. Cyclosporine, FK506 and other drugs in organ transplantation. Curr Opin Immunol 1991; 3: 748-51.

13 Gonwa TA, Klintmalm GB, Husberg BS, et al. Liver transplantation in patients with preLiver transplantation in patients with pre-
existing renal failure. Transplant Proc 1988; 20: 561-3.

14 Sherlock S, Shaldon S. The etiology and management of ascites in patients with hepati cirrhosis. A review. Gut 1963, 4: 95-105.

15 Lieberman FL, Denison EK, Reynolds TB. The relationship of plasma volume, portal hypertension, ascites and renal sodium retention in cirrhosis: the overflow theory of ascites
formation. Ann NY Acad Sci 1970; 170: 202-6.

16 Schrier RW, Arroyo V, Bernardi M, Epstein M, Henriksen JH, Rodes J. Peripheral arterial vasodilatation hypothesis: a proposal for the initiation of renal sodium and water retention in cirrhosis. Hepatology 1988; 8: 1151-7.

17 Benoit JN, Granger DN. Splanchnic hemodynamics in chronic portal hypertension. hemodynamics in chronic portal hype
Semin Liver Dis 1986; 6: 287-98.

18 Schrier RW, Niederberger M, Weigert A Gines P. Peripheral arterial vasodilatation: Gines P. Peripheral arterial vasodilatation: determinant of functional spectrum of
hosis. Semin Liver Dis 1994;14: 14-22.

19 Wong F, Blendis L. Pathophysiology of sodium retention and ascites formation in cirrhosis: role of atrial natriuretic factor. Semin Liver Dis 1994; 14: 59-70.

20 Tomita K, Ujiie K, Nakanishi T, et al. Plasma endothelin levels in patients with acute renal failure. $N$ Engl F Med 1994; 321: 1127.

21 Forns X, Gines A, Gines P, Arroyo V. Management of ascites and renal failure in cirrhosis. Semin Liver Dis 1994; 14: 82-96.

22 Laffi G, Villa GL, Gentilini P. Pathogenesis and management of the hepatorenal syndrome. Semin Liver Dis 1994; 14: 71-81.

23 Fulenwider JT, Galambor JD, Smith RB, et al. LeVeen vs Denver peritoneovenous shunt for intractable ascites of cirrhosis. A randomized prospective trial. Arch Surg 1986; 121: 351-5.

24 Tito L, Gines P, Arroyo V, et al. Total paracentesis associated with intravenous paracentesis associated with intravenous albumin in the management of patients with
cirrhosis and ascites. Gastroenterology 1990 cirrhosis and $146-51$.

25 Gines P, Arroyo V, Vargas V, et al. Paracentesis with intravenous infusion of albumin as compared to peritoneovenous shunting in cirrhosis with refractor

26 Bruno S, Borzio M, Romagnoni $\mathrm{P}$, et al Comparison of spontaneous ascites filtration and reinfusion with total paracentesis with intravenous albumin infusion in cirrhotic patients with tense ascites. $B M F$ 1992; 304 1665-8.

27 Ring EJ, Lake JR, Roberts JP, et al. Using transjugular intrahepatic portosystemic shunts to control variceal bleeding before liver transplantation. Ann Intern Med 1992; 116: 304-9.

28 Conn HO. Transjugular intrahepatic portalsystemic shunts: the state of the art. Hepatology 1993; 17: 148

29 Knechtle SJ, Kalayoglu M, D'Alessandro AM, et al. Portal hypertension: surgical management in the 1990s. Surgery 1994; 116: 687-95.
30 Rimola A, Galver JS, Schade RR, El-Lankany $S$, Starzl TE, Van Thiel DH. Effects of renal impairment on liver transplantation. Gast roenterology 1987; 93: 148-56.

31 Powell-Jackson PR, Young B, Calne RY, Williams R. Nephrotoxicity of parenterally administered cyclosporine after orthotopic liver transplantation. Transplantation 1985; 36 505-8.

32 Van Thiel DH, Schade R, Galaver J, et al. Medical aspects of liver transplantation. Hepatology 1984; 4: 795-835.

33 Iwatsuki S, Esquivel CO, Klintmalm GBG, Gordon RD, Shaw BW Jr, Starzl TE. Nephrotoxicity of cyclosporine in liver transplantatoxicity of cyclosporine in liver trans
tion. Transplant Proc 1985; 17: 191-5.

34 Danovitch GM, Wilkinson AH, Colonna JO Busuttil RW. Determinants of renal failure in patients receiving orthotopic liver transplantation. Kidney Int [Abstract] 1987; 31: 195.
35 Williams R, Blackburn A, Neuberger J, Calne RY. Long term use of cyclosporine in live grafting. Qf Med 1987; 57: 897-905.

36 Epstein M. Renal functional abnormalities in cirrhosis: pathophysiology and management. In: Zakim D, Boyer TD, eds. Hepatology. $A$ textbook of liver disease. Philadelphia: Saunders, 1982; pp 446-64.

37 Epstein M. Liver disease. In: Massry SG Glassock RJ, eds. Textbook of nephrology. Baltimore: Williams and Wilkins,

38 Ring-Larsen H, Palazzo U. Renal failure in fulminant hepatic failure and terminal cirrhosis: a comparison between incidence, types, hosis: a comparison between incidence,

39 Koppel MH, Coburn JW, Mims MM, et al. Koppel MH, Coburn JW, Mims MM, et al. pransplantation of cadaveric kidneys from patients with hepatorenal syndrome. Evidence for the functional nature of renal failure in 280: $1367-71$.

40 Park SI. Management of the end stage live disease patient. In: Neuberger J, Lucey MR, eds. Liver transplantation: practice and management. London: BMJ, 1994; pp 107-124.

41 Arroyo V, Gines P. Prostaglandins and the treatment of hepatorenal syndrome in cirrhosis. F Hepatol 1990; 11: 142-4.

42 Perez-Ayuso RM, Arroyo V, Camps J, et al. Renal kallikrein excretion in cirrhotics with ascites: relationship to renal hemodynamics. Hepatology 1984; 4: 247-52.

43 Lumsden AB, Henderson JM, Kutner $\mathrm{MH}$ Endotoxin levels measured by a chromogenic assay in portal hepatic and peripheral venous blood in patients with cirrhosis. Hepatology 1988; 8: 232-6.

44 Korula J. Hepatorenal syndrome. In: Kaplowitz $\mathrm{N}$, ed. Liver and biliary diseases. Baltimore: Williams and Wilkins, 1992 pp 542-51.

45 Starzl TE, Demetris AJ, Van Thiel D. Liver transplantation. N Engl $\mathcal{f}$ Med 1989; 321 1092-9.

46 Starzl TE, Demetris AJ. Timing of liver transplantation. In: Starzl TE, Demetris AJ, eds. Liver transplantation: a 31-year perspective. Chicago: Year Book Medical Publishers, 1990; pp 131-6.

47 Papper S. Hepatorenal syndrome. In: Epstein $\mathrm{M}$, ed. The kidney in liver disease. New York: Elsevier, 1983; pp 87-106.

48 Reynolds TB. The hepatorenal syndrome. In: Schaffner F, Sherlock S, Leevy CM, eds. The liver and its diseases. New York: Intercontinental Medical Book Corp, 1974; pp 307-13.

49 Gordon JA, Anderson RJ. Hepatorenal syndrome. Semin Nephrol 1981; 1: 37-41.

50 Iwatsuki S, Popovtzer MM, Corman JL, et al. Recovery from 'Hepatorenal syndrome' after orthotopic liver transplantation. $N$ Engl f $\mathrm{Med}$ 1973; 289: 1155-9.

51 Iwatsuki S, Esquivel CO, Gordon RD, et al. Liver transplantation for fulminant hepatic failure. Semin Liver Dis 1985; 5: 325-8.

52 Wood RP, Ellis D, Starzl TE. The reversal of the hepatorenal syndrome in four pediatric patients following successful orthotopic liver transplantation. Ann Surg 1987; 205: 415-9.

53 Stegall MD, Ploeg RJ, D'Alessandro AM, et al. Liver transplantation in patients with preLiver transplantation in patients with pre-
transplant renal insufficiency. Congress of the transplant renal insufficiency. Congress of the
International Liver Transplantation Society, 1992. (abstract)

54 Gonwa TA, Morris CA, Goldstein RM, Husberg BS, Klintmalm GB. Long term surival and renal function following liver transplantation in patients with and without hepatorenal syndrome-experience in 300 patients. Transplantation 1991; 51: 428-30.

55 Simpson KM, Bunch DL, Amemiya HJ, et al. Humoral antibodies and coagulation mechanisms in accelerated or hyperacute rejection of renal homografts in sensitized canine recipients. Surgery 1970; 68: 77-85.

56 Fung JJ, Makowka L, Griffin M, Duquesnoy RJ, Tzakis A, Starzl TE. Successful sequential liver-kidney transplantation in patients with preformed lymphocytotoxic antibodies. Clin Transplant 1987; 1: 187-94.

57 Margreiter R, Kramer R, Huber C, et al. Combined liver and kidney transplantation. Lancet 1984; 1: 1077-8.

58 Gonwa TA, Nery JR, Husberg BS, Klintmalm GB. Simultaneous liver and renal transplantaGB. Simultaneous liver and renal transplanta-
tion in man. Transplantation 1988; 46: 690-3.

59 Gonwa TA, Poplawski S, Paulsen W, et al. Pathogenesis and outcome of hepatorenal syndrome in patients undergoing orthotopic liver transplant. Transplantation 1989; 47: 395-7.

$60 \mathrm{McD}$ onald JC, Landreneau MD, Rohr MS, DeVault GA Jr. Reversal by liver transplantation of the complications of primary hyperoxaluria as well as the metabolic defect. N Engl $f$ Med 1989; 321: 1100-2.

61 Scheiman JI. Primary hyperoxaluria: therapeutic strategies for the $90 \mathrm{~s}$. Kidney Int 1991; 40: 389-99.

62 Watts RW, Calne RY, Williams R, et al. Primary hyperoxaluria (type 1): attempted treatment by combined hepatic and renal

63 Taylor JE, Calne RY, Stewart WK. Massive cystic hepatomegaly in a female patient with polycystic kidney disease treated by combined hepatic and renal transplantation. $Q \mathcal{F} M e d$ hepatic and renal

64 Uribari J, Miller C, Burrows L. Combined liver-kidney transplantation for the genetic disorder primary hyperoxaluria type I. $M t$ Sinai f Med 1994; 61: 32-6.

65 The Canadian multi-center transplant study group. A randomized clinical trial of cyclosEngl f Med 1983; 309: 809-15.

66 Morris PJ. Cyclosporine. In: Morris PJ, ed. Kidney transplantation Philadelphia: Saunders, 1989; pp 285-319.

67 Starzl TE, Klintmalm GBG, Porter KA, et al. Liver transplantation with use of cyclosporine $\mathrm{A}$ and prednisone. $N$ Engl $\mathcal{F}$ Med 1981; 305:

68 Venkataramanan R, Burckart GJ, Ptachinski RJ. Pharmacokinetics and monitoring of cyclosporine following orthotopic liver transplan tation. Semin Liver Dis 1985; 5: 357-88.

69 Schwartz ME, Manzarbeitia C, Miller CM. TL, Klion FM, eds. Guide to liver transplantation. New York: Igaku-Shoin, 1992; pp 183-97.

70 Klion FM, Fabry TL. Late postoperative management. In: Fabry TL, Klion FM, eds. Guide to liver transplantation.
Igaku-Shoin, 1992; pp 197-214.

71 Cakaloglu Y, Devlin J, O'Grady O, et al. Importance of concomitant viral infection during late acute liver allograft rejection. Transplantation 1995; 59: 40-5.

72 Sandborn WH, Lawson GM, Cody TJ, et al. Early cellular rejection after orthotopic liver transplantation correlates with low concentrations of FK506 in hepatic tissue. Hepatology 1995; 21: 70-6.

73 Myers BD, Newton L, Boshkos C, et al. Chronic injury of human renal microvessels with low dose cyclosporine therapy. Transplantation 1988; 46: 694-703.

74 Kanazi G, Stowe N, Steinmuller D, Ho-Hsieh $\mathrm{H}$, Novick AC. Effects of cyclosporine upon the function of ischemically damaged kidneys in the rat. Transplantation 1986; $41: 782-4$.

75 Hamilton DV, Calne RY, Evans DB, Henderson RG, Thiru S, White DJG. The effect of long-term cyclosporine

76 Duarte R. Cyclosporine: renal effects and prostacyclin. Ann Intern Med 1985; 102: 420.

77 Coffman TM, Carr DR, Yarger WE, Klotman PE. Evidence that renal prostaglandin and thromboxane production is stimulated in chronic cyclosporine nephrotoxicity. Transplantation 1987; 43: 282-5.

78 Sandborn WJ, Hay JE, Porayko MK, et al. Cyclosporine withdrawal for nephrotoxicity in liver transplant recipients does not result in sustained improvement in kidney function and causes cellular and ductopenic rejection. Hepatology 1994; 19: 925.

79 Jindal RM. Posttransplant diabetes mellitus - a review. Transplantation 1994; 58: 1289-98.

80 Siekierka JJ, Hung SH, Poe M, Lin CA, Sigal NH. A cytosolic binding protein for the immunosuppressant FK506 has peptidy prolyl isomerase activity but is distin
cyclophilin. Nature 1989; 341: 755-7.

81 Todo S, Ueda Y, Demetris AJ, et al. Immunosuppression of canine, monkey, and baboon allografts by FK506 with special reference to synergism with other drugs, and to tolerance induction. Surgery 1988; 104: tolerance

82 Todo S, Fung JJ, Demetris AJ, et al. Early trials with FK506 as primary treatment in liver transplantation. Transplant Proc 1990; 22 13-6.

83 McCauley J, Fung JJ, Todo S, Jain A, Deball 
84 European FK506 multicenter liver study group. Randomised trial comparing tacrolimus FK506) and cyclosporin in prevention of liver allograft rejection. Lancet 1994; 344: 423-8.

85 The US multicenter FK 506 liver study group. A comparison of tacrolimus (FK506) and cyclosporine for immunosuppression in liver transplantation. $N$ Engl $\mathcal{f}$ Med 1994; 331: 1110-5.

86 Platz KP, Mueller AR, Blumhardt G, et al. Nephrotoxicity following orthotopic liver transplantation: A comparison between cyclosporine and FK506. Transplantation 1994; 58: porine and
$170-8$.

87 Todo S, Fung JJ, Starzl TE, et al. Singlecenter experience with primary orthotopic liver transplantation with FK506 immunosup pression. Ann Surg 1994; 220: 297-309.

88 Jindal RM, Popescu I, Sukru E, et al. Serum lipid changes in a prospective trial of cyclosporine versus FK506 in liver transplant recipients. Transplantation 1994; 57: 1395-8.

89 Neuhaus P, Blumhardt G, Bechstein WO, et al. Comparison of FK506- and cyclosporinebased immunosuppression in primary orthotopic liver transplantation. Transplantation 1995; 59: 31-40.

90 Demetris AJ, Fung JJ, Todo S, et al. Conversion of liver allograft recipient from cyclosporine to FK506 immunosuppressive therapy - a clinicopathological study of 96 patients. Transplantation 1992; 53: 1056-62.

91 Thiru S, Collier D StJ, Calne R. Pathological studies in canine and baboon renal allograft
recipients immunosuppressed with FK506. recipients immunosuppressed with

92 Ochiai $T$, Hamaguchi $K$, Isono $K$. Histologic studies in renal transplant recipient dogs receiving treatment with FK506. Transplant Proc 1987; 21: 93-7.

93 Stephen M, Woo J, Hasan NU, Thompson AW. Immunosuppressive activity, lymphocyte subset analysis, and acute toxicity of FK506 in the rat. A comparative and combination study with cyclosporine. Transplantation 1989; 47: $60-5$.

94 Moutabarrik A, Ishibashi M, Fukunga M, et al. FK506 induced kidney cell injury. Transplantation 1992; 54: $1041-7$.

95 Benigni A, Morigi M, Perico N, et al. The acute effect of FK506 and cyclosporine on endothelial cell function and renal vascular resistance. Transplantation 1992; 54: 775-80.

96 Textor SC, Wiesner R, Wilson DJ, et al. Systemic and renal hemodynamic differences Systemic and renal hemodynamic differences
between FK506 and cyclosporine in liver between FK506 and cyclosporine in liver
transplant recipients. Transplantation 1993; transplant

97 Millis JM, McDiarmid SV, Hiatt JR, et al. Randomized prospective trial of OKT3 for early prophylaxis of rejection after liver transplantation. Transplantation 1989; 4: 82-8.

98 Millis JM, Baquerizo A, Saleh S, Danovitch GM, Busuttil RW. Preservation of renal function using OKT 3 in liver transplant patients. Transplant Proc 1989; 21: 3551-2.
99 Houghton S, Frei JV, Ghent CN. Use of OKT 3 in liver transplant patients. Transplantation 1989; 48: 1079 .

100 Hamilton G, Muhlbacher M, Steininger R, et al. Lymphocyte parameters in liver grafts recipients receiving prophylactic OKT3 or conventional triple therapy. Transplant Proc 1989; 21: 2255-6.

101 First MR, Schroeder TJ, Hurtubise PE, et al. Successful retreatment of allograft rejection
with OKT3. Transplantation 1989; 47: 88-91.

102 McDiarmid SV, Millis M, Terashita G, Ament ME, Busuttil R, Terasaki P. Low serum OKT3 levels correlate with failure to prevent rejection in orthotopic liver transplant rejection in orthotopic liver transplan

103 McDiarmid SV, Millis MJ, Terasaki PI, Ament ME, Busuttil RW. OKT3 prophylaxis in liver transplantation. Dig Dis Sci 1991; 36: 1418-26.

104 Renard TH, Andrews WS, Foster ME. Relationship between OKT3 administration, EBV seroconversion, and the lymphoproliferative syndrome in pediatric liver transplant recipients. Transplant Proc 1991; 3: 1473-6.

105 Jindal RM, Tepper MA, Soltys K, Cho SI Deoxyspergualin - a new novel immunosuppressant. Mt Sinai $\mathcal{F}$ Med 1994; 61: 51-6.

106 Platz KP, Eckhoff DE, Hullet DA, Sollinger HW. RS-61443 studies: review and proposal. Transplant Proc 1991; 23: 33-5.

107 Toto RD. The role of prostaglandins in NSAID-induced renal dysfunction. Rheumatol 1991; 28: 22-5.

108 Pomer S, Rohl L, Hull W, et al. Reduction of cyclosporine nephrotoxicity by prostaglandin $E_{2}$ after experimental renal transplantation. Transplant Proc 1987; 19: 4041 -2.

109 Grazi GL, Maziotti A, Sama C, Stefanini GF, Gozzetti G. Reversal of primary graft nonfunction using prostaglandins. Hepatogastroenterology 1991; 38: 254-6.

110 Miyazaki M, Makowka L, Falk RE, et al. Protection of thermochemotherapeuticinduced lethal acute hepatic necrosis in the rat by 16,16-dimethyl prostaglandin $\mathrm{E}_{2}$. F Surg Res 1983; 34: 415-26.

111 Sinclair SB, Greig PD, Blendis LM, et al. Biochemical and clinical response of fulminant viral hepatitis to administration of prostaglandin E: a preliminary report. $\mathcal{f}$ Clin Invest 1989 ; 84: $1063-9$.

112 Sheiner P, Sinclair S, Greig P, Logan A Blendis $L M$, Levy $G$. A randomized control
trial of prostaglandin $E_{2}$ in the treatment of trial of prostaglandin $E_{2}$ in the treatment of
fulminant hepatic failure. Hepatology 1992; 16: fulminar.

113 Kaufman RP, Anner H, Kobzik L, Valeri CR, Shepro D, Hechtman H. Vasodilator prostaglandins (PG) prevent renal damage after ischemia. Ann Surg 1987; 205: 195-8.

114 Greig PD, Woolf GM, Sinclair SB, et al Treatment of primary liver graft nonfunction with prostaglandin $\mathrm{E}_{1}$. Transplantation 1989 ;
48: $447-53$.
115 Moran M, Mozes MF, Maddux MS, et al Prevention of acute graft rejection by prostaglandin $\mathrm{E}_{1}$ analogue Misoprostol in renal trans plant recipients treated with cyclosporine and prednisone. N Engl ₹ Med 1990; 322: 1183-8.

116 Adams MB and the enisoprost renal transplan study group. Eniprost in renal transplantation. Transplantation 1992; 53: 338-45.

117 McCauley J, Gaynord M, Hrinya M, Starzl TE. Dialysis in liver failure and liver transplantation. Transplant Proc 1993; 25: 1740.

118 Opolon $\mathrm{P}$, Rapin JR, Huguet C. Hepatic failure coma treated by polyacrylonitrile membrane coma treated by polyacrylonitrile membrane 1976; 22: 701 .

119 Hakim RM, Wingard RL, Parker RA. Effect of the dialysis membrane in the treatment of patients with acute renal failure. $N \mathrm{Engl} \mathcal{F} \mathrm{Med}$ 1994; 331: 1338-42.

120 Schiff H, Lang SM, Konig A, Strasser T Haider MC, Held E. Biocompatible membranes in acute renal failure: prospective casecontrolled study. Lancet 1994; 344: 570-2.

121 Rozga J, Podesta L, LePage E, et al. A bioartificial liver to treat severe acute liver failure. Ann Surg 1994; 219: 538-46.

122 Chari RS, Collins BH, Magee JC, et al. Treatment of hepatic failure with ex vivo pig-liver perfusion followed by liver transplantation. $N$ Engl f Med 1994; 331: 234-7.

123 Rozga J, Podesta L, Le Page E, et al. Control of cerebral edema by total hepatectomy and extracorporeal liver support in fulminant hepatic racorporeal liver support in fulm

124 Starzl TE, Fung J, Tzakis A, et al. Baboon-tohuman liver transplantation. Lancet 1993; 341 65-71.

125 Sheiner PA, Schwartz ME, Mor E, et al. Severe or multiple rejection episodes ar associated with early recurrence of hepatitis $C$ after orthotopic liver transplantation. Hepatology 1995; 21: 30-4.

126 Misiani R, Bellavita P, Fenili D, et al. Hepatitis $C$ virus infection in patients with essential mixed cryoglobulinemia. Ann Intern Med 1992; 117: 573-7.

127 Misiani R, Bellavita P, Fenili D. Hepatitis C virus and cryoglobulinemia. $N$ Engl $f \mathrm{Med}$ 1993; 328: 1121 .

128 Cacoub P, Lunel F, Musset L, Opolon P, Piette JC. Hepatitis $\mathrm{C}$ virus and cryoglobulinemia. $N$ Engl f Med 1993; 328: $1121-2$.

129 Agnello V, Chung RT, Kaplan LM. A role for hepatitis $C$ virus infection in Type II cryoglubulinemia. $N$ Engl f Med 1992; 327: 1490-5.

130 Werner C, Joller-Jemelka HI, Fontana A. Hepatitis C virus and cryoglo
Engl f Med 1993; 328: 1122-3. 